Tarih Kültür ve Sanat Araştırmaları Dergisi

Revue des Recherches en Histoire Culture et Art

مجلة البحوث التاريخية و الثقافية والفنية
Vol. 6, No. 1, February 2017

Copyright (C) Karabuk University

http:..kutaksam.karabuk.edu.tr

\title{
DOI: 10.7596.taksad.v6i1.709
}

Citation: Jamali, M., Mehrabadi, M., \& Pouri, M. (2017). The Effect of the Implementation of E-Crm Electronic Satisfaction and Loyalty, Electronic Consumers of Mellat Bank's Website. Journal of History Culture and Art Research, 6(1), 121-135. doi:http://dx.doi.org/10.7596/taksad.v6i1.709

\section{The Effect of the Implementation of E-Crm Electronic Satisfaction and Loyalty, Electronic Consumers of Mellat Bank's Website}

\author{
Mehdi Jamali $^{1}$, Mohammad Azimi Mehrabadi*2 ${ }^{2}$ Mohammad Pouri ${ }^{3}$
}

\begin{abstract}
Organizations that compete for power in the market constantly looking for ways to overcome their rivals. Today's customers want to engage with the organization. Successful customer relationship management is one of the major competitive advantages that organizations can use to prevent the transmission of clients to other organizations deemed of operation. The degree to which an organization is able to maintain effective communication with their clients, more opportunities to offer more services to its business customers will offer. Considering the above study to evaluate the effect of the implementation of E-CRM on esatisfaction and customer loyalty has paid electronically, users of the Mellat Bank's website. To collect information from the questionnaire with Cronbach's alpha was used validation. Respondents were customers and users of online services of the Mellat Bank's website. Survey research method - has been described. To analyze the data, descriptive and inferential statistical methods such as correlation analysis, Pearson and Spearman correlation coefficient and linear regression analysis using SPSS software is used. The results show that the implementation of E-CRM is a positive and significant impact on customer satisfaction and loyalty-mail.
\end{abstract}

Keywords: Electronic Consent, Loyalty-Mail, E-CRM.

\footnotetext{
${ }^{1}$ Islamic Azad University of Farahan Senior Student of Executive Management.

${ }^{2}$ Corresponding Author, Islamic Azad University, Science and Research Branch, Tehran, Iran Department of Industrial Engineering. Dr.mohazimi@gmail.com

${ }^{3}$ Islamic Azad University of Farahan Senior Student of Executive Management.
} 


\section{Introduction}

Companies that constantly vie for power on the market "to find ways to overcome their rivals. Successful customer relationship management is one of the major competitive advantages that companies can take to prevent the transfer of customers to the company exploited certainties (Sculin et al., 2002). The degree to which a company can maintain effective communication with their clients, more opportunities to provide more service and product to its customers will gain (Peine and fall, 2005). While more or less one-dimensional problems related to their performance using enterprise resource planning systems have solved, and now, with the election of customer relationship management systems, to improve their multi-dimensional functions in order to increase their value to customers focus (Anderson \& Kerr, 2001). Customer relationship management is able to reduce the gap between customers and organizations with customer loyalty, superior service, better information gathering and organizational learning, organizational strengthening (Cao and Clemez, 2004). The main goal of CRM is to simply understand better the behavior of the customers in order to increase loyalty and benefits (Lee and Joshi, 2006). Customer relationship management, in addition to maximizing customer satisfaction, strategic process for the formation of the interaction between a company and the company tells customers (Lin et al., 2005).

It is clear that customer relationship management is a systemic issue, because marketing (such as relationship marketing, consumer behavior, etc.), system information (such as e-commerce, human-computer interaction,), management other deals (Anderson \& Kerr, 2001). In fact, customer relationship management all processes that organization to identify, select, promote, develop, retain, and serve customers to take ( $\mathrm{Lu}, 2003)$.

Customer relationship management systems help organizations maximize their ability to interact with their customers. This leads not only to improve the quality, but also increases the speed of response to customer needs (Anderson and Syrynavasan, 2003) and this concern is elevated corporate executives. Today customers expect that other companies do not like and quickly respond to customer needs is one of the Company's competitive advantage companies have to react and attention to the issue of e-CRM.

\subsection{Theoretical Basis}

In the last years with developments in information and communication technologies creates new concepts of globalization, freedom, and increase innovation, continuous reduction of product life cycles and witnessing the dawn of the concept of customer relationship management (CRM) as a title in the business approach that aims to return to the era of personalized marketing is seen.

There are various definitions of E-CRM in the literature. The simplest Internet connection and E-CRM CRM calls. This expansion is traditional CRM. Jvtla and colleagues (2001) E-CRM customer relationship defined as a component of their care. Greenberg (2000) E-CRM and the CRM Online calls. According to Romano attraction and retaining customers who are economically profitable and remove those that do not benefit is determined. Table 1 summarizes the major differences between CRM and E-CRM show. 
Table 1: lists the differences between CRM and ECRM

\begin{tabular}{|c|c|c|c|c|}
\hline Dimension & E-CRM & CRM & References & \\
\hline $\begin{array}{l}\text { Contact } \\
\text { Customer }\end{array}$ & $\begin{array}{l}\text { Internet,e-mail, } \\
\text { wireless, mobile }\end{array}$ & $\begin{array}{l}\text { Traditional means of } \\
\text { online retailers, phone } \\
\text { or fax }\end{array}$ & $\begin{array}{l}\text { Chandra } \\
\text { Stickland,(2004) } \\
\text { Lee,(2003) }\end{array}$ & $\begin{array}{r}\text { and } \\
\text { Pan and }\end{array}$ \\
\hline $\begin{array}{l}\text { Customer } \\
\text { Service }\end{array}$ & $\begin{array}{l}\text { At any time and } \\
\text { from any location }\end{array}$ & $\begin{array}{l}\text { Time and space } \\
\text { constraints }\end{array}$ & $\begin{array}{l}\text { Chandra } \\
\text { Stickland,(2004) } \\
\text { Lee,(2003) }\end{array}$ & $\begin{array}{ll} & \text { and } \\
\text { Pan } & \text { and }\end{array}$ \\
\hline $\begin{array}{l}\text { Customization } \\
\text { Information }\end{array}$ & $\begin{array}{l}\text { Easy to customize } \\
\text { information for } \\
\text { each person }\end{array}$ & $\begin{array}{l}\text { Customization is } \\
\text { possible } \\
\text { customizationrequires } \\
\text { fundamental changes } \\
\text { in the system }\end{array}$ & $\begin{array}{l}\text { Chandra } \\
\text { Stickland,(2004) } \\
\text { Lee,(2003) }\end{array}$ & $\begin{array}{l}\text { and } \\
\text { and }\end{array}$ \\
\hline Focus System & Customer needs & $\begin{array}{l}\text { Products and job } \\
\text { functions }\end{array}$ & $\begin{array}{l}\text { Chandra } \\
\text { Stickland,(2004) } \\
\text { Lee,(2003) }\end{array}$ & $\begin{array}{l}\text { and } \\
\text { and }\end{array}$ \\
\hline System Design & $\begin{array}{l}\text { The system is } \\
\text { designed for the } \\
\text { entire collection }\end{array}$ & $\begin{array}{l}\text { The system is } \\
\text { designed for an } \\
\text { apartment or business } \\
\text { unit }\end{array}$ & $\begin{array}{l}\text { Chandra } \\
\text { Stickland,(2004) }\end{array}$ & and \\
\hline
\end{tabular}

Process E-CRM includes four main components: the commitment, buy, carry out and support Table 2 or Table 4 shows the characteristics of E-CRM important loss in the transaction cycle.

Table 2: Describes the features of E-CRM before you buy

\begin{tabular}{|c|c|c|}
\hline $\begin{array}{c}\text { Features of E-CRM before } \\
\text { you buy }\end{array}$ & Comment on Research & Authors \\
\hline $\begin{array}{r}\text { Introduction for new users } \\
\text { Customization Site } \\
\text { Other channels } \\
\text { Local search machine } \\
\text { Membership } \\
\text { Circulation on the site, } \\
\text { sitemap, chat } \\
\text { Electronic Bulletin }\end{array}$ & $\begin{array}{r}\text { Express electronic Customer } \\
\text { Relationship Management in } \\
\text { Retail }\end{array}$ & Feinberg et al(2002) \\
\hline $\begin{array}{r}\text { Cross selling and up-selling } \\
\text { Marketing Promotions } \\
\text { Customer retention } \\
\text { Management Response } \\
\text { Email marketing }\end{array}$ & $\begin{array}{l}\text { E-CRM from the perspective } \\
\text { of supply chain management }\end{array}$ & Ross(2005) \\
\hline $\begin{array}{r}\text { Customization Site } \\
\text { Other channels } \\
\text { Customer training }\end{array}$ & $\begin{array}{l}\text { The effects of CRM Online } \\
\text { customer satisfaction }\end{array}$ & Khalifa and Shen(2005;2009) \\
\hline $\begin{array}{r}\text { Quality Information } \\
\text { Web Design } \\
\text { Special product }\end{array}$ & \begin{tabular}{lrr} 
An & \multicolumn{2}{c}{ experimental } \\
investigation of customer \\
satisfaction of online \\
shopping in China: a total \\
\multicolumn{2}{c}{ experience } \\
\end{tabular} & Liu et al(2008) \\
\hline Product Support & experimental & Otim and Grover(2006) \\
\hline
\end{tabular}




\begin{tabular}{|r|r|r|r|}
\hline \multicolumn{2}{|r|}{$\begin{array}{r}\text { Search and Compare } \\
\text { Beauty Website }\end{array}$} & $\begin{array}{l}\text { investigation of customer } \\
\text { loyalty and } \begin{array}{r}\text { Web-based } \\
\text { services }\end{array}\end{array}$ & \\
\hline $\begin{array}{r}\text { Convenience, choice, price } \\
\text { transparency, see, shipping, } \\
\text { commitment }\end{array}$ & $\begin{array}{l}\text { Satisfaction before and after } \\
\text { purchase: the impact on } \\
\text { overall satisfaction and } \\
\text { repurchase intentions }\end{array}$ & Posselt and Gerstner(2005) \\
\hline $\begin{array}{l}\text { Web design, price, } \\
\text { promotion, product } \\
\text { availability }\end{array}$ & $\begin{array}{r}\text { Electronic satisfaction in } \\
\text { order to determine the phases } \\
\text { before and after order }\end{array}$ & Wang and Hurang(2004) \\
\hline
\end{tabular}

Table 3: describes the features of E-CRM when buying

\begin{tabular}{|c|c|c|}
\hline $\begin{array}{c}\text { Dimensions of E-CRM } \\
\text { features when buying }\end{array}$ & Comment on Research & Authors \\
\hline $\begin{array}{c}\text { online shopping } \\
\text { Product information } \\
\text { Customise } \\
\begin{array}{c}\text { Terms \& Conditions } \\
\text { Product preview } \\
\text { links }\end{array}\end{array}$ & Express CRM Online retail & Feinberg(2002) \\
\hline $\begin{array}{c}\text { Product customization } \\
\text { Payment methods } \\
\text { Terms \& Conditions } \\
\text { Buy comparative } \\
\text { Pricing fluid }\end{array}$ & $\begin{array}{c}\text { The effects of CRM Online } \\
\text { customer satisfaction }\end{array}$ & Khalifa and Shen(2005;2009) \\
\hline $\begin{array}{c}\text { The transaction } \\
\text { Security and Privacy } \\
\text { Pay }\end{array}$ & $\begin{array}{c}\text { An empirical study on online } \\
\text { shopping and satisfaction in } \\
\text { China: a comprehensive } \\
\text { study }\end{array}$ & \\
\hline $\begin{array}{c}\text { Order delivery } \\
\text { Transparency bill }\end{array}$ & $\begin{array}{c}\text { An empirical study on Web- } \\
\text { based services and customer } \\
\text { loyalty }\end{array}$ & Otim and Grover(2006) \\
\hline
\end{tabular}

Table 4: describes the features of E-CRM after purchase

\begin{tabular}{|c|c|c|}
\hline $\begin{array}{c}\text { E-CRM features after } \\
\text { purchase }\end{array}$ & Comments on Research & Authors \\
\hline $\begin{array}{c}\text { FAQ } \\
\text { Solving problems } \\
\text { Comparability } \\
\text { spare parts }\end{array}$ & $\begin{array}{c}\text { Express electronic Customer } \\
\text { Relationship Management in } \\
\text { Retail }\end{array}$ & Feinberg et al(2002) \\
\hline $\begin{array}{c}\text { Solving problems } \\
\text { Channels reaction } \\
\text { tracking the order } \\
\text { Online Forum } \\
\text { Web Center }\end{array}$ & $\begin{array}{c}\text { The effects of CRM Online } \\
\text { customer satisfaction }\end{array}$ & Khalifa and Shen(2005;2009) \\
\hline $\begin{array}{c}\text { Delivery } \\
\text { Customer Service }\end{array}$ & $\begin{array}{c}\text { An empirical study of online } \\
\text { shopping and customer } \\
\text { satisfaction in China: a } \\
\text { comprehensive study }\end{array}$ & Liu et al(2008) \\
\hline
\end{tabular}




\begin{tabular}{|c|c|c|}
\hline $\begin{array}{c}\text { tracking the order } \\
\text { Prompt delivery } \\
\text { Customer service }\end{array}$ & $\begin{array}{c}\text { An empirical study on Web- } \\
\text { based services and customer } \\
\text { loyalty }\end{array}$ & Otim and Grover(2006) \\
\hline $\begin{array}{c}\text { Availability, track } \\
\text { Being punctual, expected } \\
\text { track }\end{array}$ & $\begin{array}{c}\text { Electronic satisfaction before } \\
\text { and after purchase: the } \\
\text { impact on overall satisfaction } \\
\text { and repurchase intentions }\end{array}$ & Posselt and Gerstner(2005) \\
\hline $\begin{array}{c}\text { Prompt delivery } \\
\text { Expectations met } \\
\text { Returns policy } \\
\text { Customer Service }\end{array}$ & $\begin{array}{c}\text { Measuring satisfaction order } \\
\text { books in phases before and } \\
\text { after }\end{array}$ & Wang and Hurang(2004) \\
\hline
\end{tabular}

Talk about electronic consent is subject of interest of many researchers .Anderson argued that satisfaction has a significant impact on loyalty and customer retention. Anderson and Sullivan (1993) claim that customer satisfaction experiencing a frank assessment now is that just a good feeling, indifference or feeling is bad. Dara (2002) argue that the ease of use and usefulness of online shopping combined with low economic costs, such as time and engaging for quality goods, price, afford paying the price and quality of service are the factors that affect customer satisfaction and ultimately form their priority. Anderson and Sullivan (1993); Fornell (1992), inclusion and colleagues (1998), the importance of service quality as a prerequisite for customer satisfaction determined. Feinberg and his colleagues (2000) reported that 68 percent of customers due to "poor service experience" along with other factors like price (10 percent) and disability (17\%) do not go to the company in question. Classified as a result of various models of customer satisfaction following points should be considered:

- Many studies have shown that if the design is not complex and easy to use it will lead to customer satisfaction.

- Few studies such as the caliph and sand between the characteristics of E-CRM and transaction cycle and customer lifecycle to determine customer satisfaction.

- Many studies show that people with different goals, such as saving time, convenience, entertainment or information and Internet use.

- Variety of products, price, and customer service and product warranty are important factors in generating customer satisfaction

- Security of online shopping is the main reason for keeping customer.

More studies loyalty as a purchase that product or service definition. Due to heavy competition and encouragement and a different price in the market, companies are looking for strategies that increase customer loyalty. Businesses on the Internet with major challenges such as seeking customers for the benefit of the price, data quality and compare prices face. Barry (1995, 2002) believes that "customer loyalty emphasis on natural interaction relationship between the market and can be a confirmation for the individual nature of the firm's commitment to customers"

For many years, many efforts have been made to obtain a specific structure for loyalty. Researchers measure attitudinal and behavioral methods to identify and achieve their loyalty. Recently loyalty and support is seen to see repeated. Oliver (1999) says that "a permanent customer loyalty and a deep commitment to purchase or a product or service in the future is certain, namely frequent purchase of a brand, despite the effects of the market situation and the efforts that will change customer behavior ". In addition, Oliver (1999) for four steps of the loyalty were shown in Figure 1 below. 


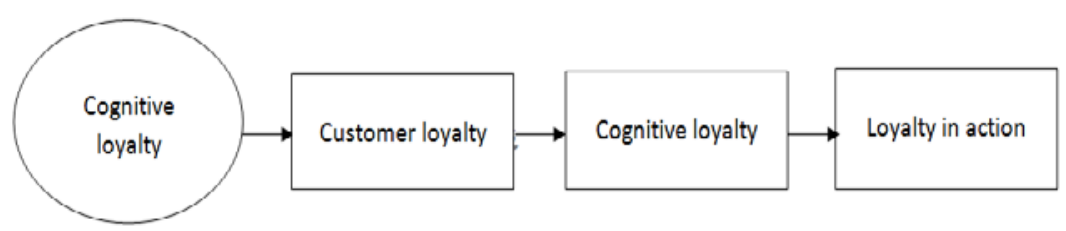

Figure 1: The four-stage model of loyalty Oliver

\subsection{Background research}

Asgharpour and colleagues (2012) conducted a study to investigate the effect of innovation on the market share in textile, leather and clothing did Iran. The dependent variable volatility of market share and market share, while the dependent variable in this study, the concentration of 4 large enterprises. The results showed a nonlinear relationship between innovation and market share in this industry.

Zamani moqaddam and Lahiji (2012) study of factors affecting customer loyalty Parsian Bank and Eghtesad-Novin Bank organizations to respond quickly based on quality of service, reliability, speed of service, flexibility, innovation and image and effect they did customer loyalty. The samples were 270 customers of the bank. The results show that the quality of service, reliability, speed of service delivery, vision, innovation and flexibility the two banks had the highest impact on customer loyalty.

Tazry and Bolourian Tehrani (2012) conducted a study aimed at measuring the key success factors in customer relationship management and insurance companies in order to identify strengths and weaknesses in implementing customer relationship management did all the research population experts, managers and Insurance Center has been organized in Tehran and the 191 people, 128 of whom were chosen. Other factors to be average.

Abesy and colleagues (2011) conducted a study to identify and prioritize the favorable factors in the successful implementation of customer relationship management from the perspective of insurance company employees did entrepreneur. The results show that the greatest impact in the technology component of the successful implementation of customer relationship system and then the components of proper organization, knowledge management and the priority components focus on key customers the greatest impact on the implementation of the system of communication with their client.

Karimi and Mansourian (2012) the quality of working life of customer relationship management in government agencies Kordestan, Marivan examined. The population of this research is 600 persons, 234 of them were selected. The results show that all the components of the quality of working life (the payment of fair wages and benefits to employees, health and safety Youden's working environment, providing opportunities for staff development and continuous security, the rule of law in the organization, integration and social cohesion of employees, dependence employees' social life and development capabilities), but the overall atmosphere of life have a direct relationship with the customer relationship management.

Harrigan and colleagues (2009) conducted a study to investigate the electronic customer relationship management activities in small and medium companies were Irish. Findings confirmed that companies with a greater emphasis on international markets to take advantage of more of its electronic customer relationship management focus and profit from increased customer service and reduce the cost of business and increased sales and improved profitability varies.

Wang (2008) for the purpose of customer relationship management system implementation and development of theoretical and experimental electronic library electronic customer relationship management system and its impact on the quality of their search services. This research was conducted in Taiwan for academic libraries. The results show that the general 
perception of the respondents to the quality of services, customer relationship management, electronic neutral or positive.

Anmala and Kyshier (2007) Benefits of e-CRM for banks and their customers and found two Swedish banks. Results benefits of electronic customer relationship management considers the following; maintain relationships with customers, providing personalized efficient service to individual customers, the availability of the latest updated information on the website of the organization and improve the security of customer transactions. As well as advantages for clients such as: ease and convenience, speed and accuracy in the transfer of money, personnel reliability and availability of the latest information technology and total confidence in the organization.

Seeman and O'Hara (2006) looked at customer relationship management in higher education. Use of information systems to improve communication between school children, the benefits of implementing customer relationship management shows that include a focus on student improvement and to provide clients information, process management, increase students' loyalty, retention and satisfaction along with their university applications.

Sin (2005) did an investigation with the aim of developing a reliable and valid scale for customer relationship management and its effect on the performance of financial institutions in Hong Kong. In this study, customer relationship management component focusing on four key clients, organizing customer relationship management, knowledge management and customer relationship management technology was chosen based on its relationship with major and minor business functions, including marketing performance (reliability and customer satisfaction) and financial performance (return on investment and return on sales) was investigated. The results show that the customer relationship management and business performance is positive.

\subsection{Goals}

The main objective:

Its website features and user satisfaction with e-customer loyalty.

Secondary objectives:

The first sub-goal: Effect of E-CRM features before you buy the e-customer satisfaction.

Sub-goal II: Effect of E-CRM features when buying consumer electronics satisfaction.

The third sub-objective: To evaluate the effect of the characteristics of E-CRM electronic customer satisfaction after purchase.

Sub-goal IV: The effect of satisfaction on loyalty e-mail.

The purpose of sub-V: Effect of E-CRM features before buying the loyalty of consumer electronics.

The purpose of sub-Six: Effect of E-CRM features when buying the loyalty of consumer electronics.

The purpose of seventh sub: Effect of the characteristics of E-CRM electronic after buying the loyalty of customers.

\section{Material and Methods}

The study objective is applied, because in order to develop practical knowledge in the field of modern marketing management is carried out and in terms of data collection, descriptive and correlational, because the relationships and the influence of independent variables with variable or dependent variable (customer loyalty) will pay.

The population of this research were customers and users of Mellat Bank's website. The assessment tool was questionnaire variables. In order to study and data analysis methods and statistical techniques were used in this study. The first data in Excel sorted and classified and some indicators and initial figures were obtained by the software, using specialized software 
such as SPSS statistical analysis was statistical data. In order to analyze research data using any of the questions or assumptions are bidirectional correlation coefficient was used.

It is noteworthy that the hypotheses of the study includes "test the relationship between satisfaction and loyalty Online" and "Online test the relationship between the ECRM and loyalty" of multiple regression analysis were used.

\section{Results}

$3.3 \%$ of subjects less than one hour, $25 \%$ between 1 and 2 hours and $18.6 \%$ of 2 to 3 hours of Internet use, according to the results, $25 \%$ of participants 3 to 5 hours and $21.9 \%$ of participants more than 5 hours your daily spending using the internet. $6.1 \%$ of participants did not respond to this question. It should also be noted that all respondents shop online, receive news and using social networks as one of the reasons for their use of the Internet and expression.

Table 5: descriptive information on the respondents use the Internet

\begin{tabular}{|r|c|c|}
\hline Item & Percent & $\begin{array}{c}\text { Quantit } \\
\mathbf{y}\end{array}$ \\
\hline $\begin{array}{r}\text { Lower than 1 } \\
\text { hour }\end{array}$ & 3.3 & 12 \\
\hline 1-2 hour & 25 & 90 \\
\hline 2-3 hour & 18.6 & 67 \\
\hline 3-5 hour & 25 & 90 \\
\hline $\begin{array}{r}\text { More than 5 } \\
\text { hour }\end{array}$ & 21.9 & 79 \\
\hline $\begin{array}{r}\text { Unresponsive } \\
\text { Total }\end{array}$ & 100 & 22 \\
\hline
\end{tabular}

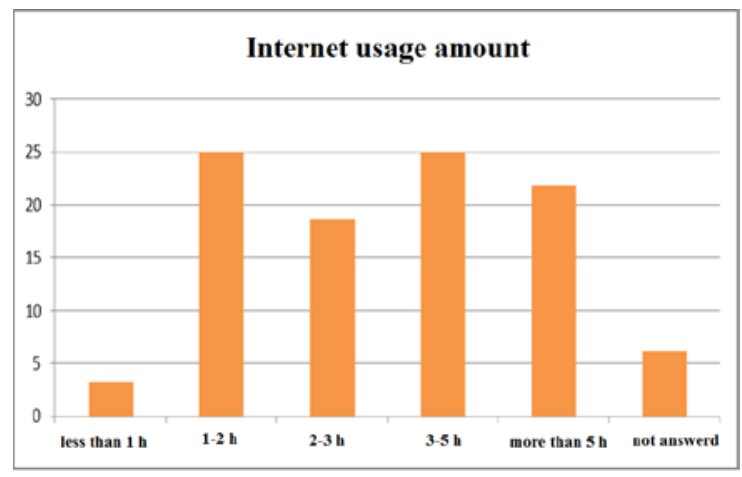

Figure 2: Diagram of the respondents use the Internet

Using correlation analysis to study the relationship between the manufacturers made an initial contact. This type of communication or correspondence between productive factors can be correlation coefficients for two-way constructive elements used. In the following correlation matrix, correlations Points for each factor is given manufacturer. Table 6 below shows the correlation between the underlying constituents of hypotheses.

Table 6: The relationship between the manufacturers of hypotheses

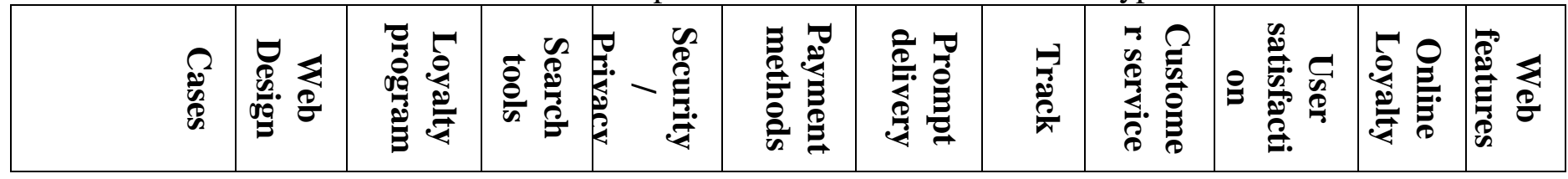




\begin{tabular}{|c|c|c|c|c|c|c|c|c|c|c|}
\hline 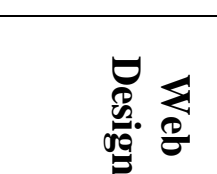 & - & & & & & & & & & \\
\hline 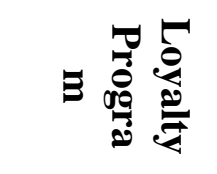 & $\check{0}$ & - & & & & & & & & \\
\hline 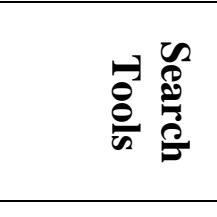 & $\dot{0}$ & $\dot{m}$ & - & & & & & & & \\
\hline 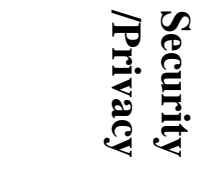 & $\dot{b}$ & $\dot{E}$ & 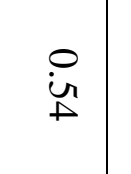 & - & & & & & & \\
\hline 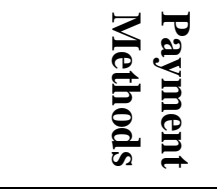 & 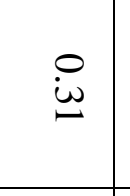 & ¿̊ & 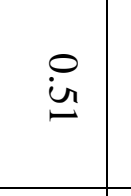 & $\stackrel{0}{2}$ & - & & & & & \\
\hline 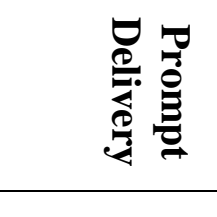 & i & 站 & 号 & $\begin{array}{l}0 \\
0 \\
0\end{array}$ & - & $\AA$ & & & & \\
\hline 旁 & $\stackrel{D}{i}$ & 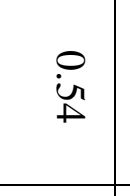 & $\stackrel{0}{ \pm}$ & 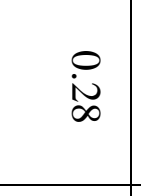 & 紊 & 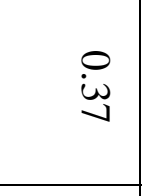 & - & & & \\
\hline 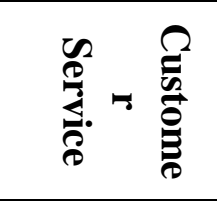 & $\stackrel{8}{8}$ & 兽 & 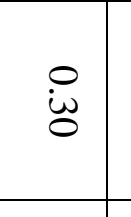 & 竎 & in & 离 & 号 & - & & \\
\hline 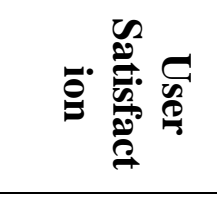 & $\stackrel{D}{\Xi}$ & $\stackrel{\circ}{\varpi}$ & 怘 & 总 & 品 & $\stackrel{D}{i}$ & 总 & $:$ & + & \\
\hline 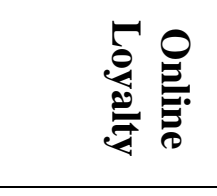 & 总 & 总 & $\stackrel{\Xi}{\tilde{m}}$ & $\stackrel{8}{8}$ & $\begin{array}{l}\mathscr{8} \\
\end{array}$ & 总 & $\stackrel{8}{:}$ & : & $\stackrel{\check{r}}{\circ}$ & - \\
\hline 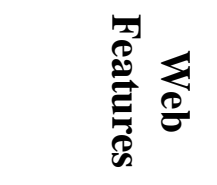 & 总 & $\stackrel{\varpi}{\circ}$ & 总 & : & ¿ & 惫 & $\mathscr{\varpi}$ & 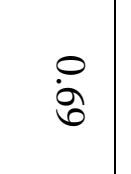 & 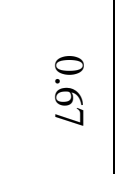 & \\
\hline
\end{tabular}


Regression: Testing the relationship between satisfaction and loyalty online

Multiple regression analysis using software Spss15 were used to investigate the relationship between satisfaction and loyalty online of users of the Mellat Bank's website. Online satisfaction is the independent variable and the dependent variable online loyalty of the Mellat Bank's website. Tables (7, 8, 9 and 10) show analysis of the relationship between satisfaction and loyalty online. The regression analysis also found that the relationship between satisfaction and loyalty online degree is verifiable by 95\%, $(\mathrm{P}<0.05)$. Also, the value of R2 adjusted 0.792 the value of the relationship is also significant indicator, the results also found that online loyalty of the Mellat Bank's website can be explained with satisfaction online. The main hypothesis of the study is confirmed (Table 7).

Table 7: evaluating the Hypothesis 2

\begin{tabular}{|c|c|c|c|}
\hline $\begin{array}{c}\text { Research } \\
\text { hypothesis }\end{array}$ & $\begin{array}{c}\text { T } \\
\text { value }\end{array}$ & $\beta$ & Results \\
\hline $\begin{array}{c}\text { Hypothesis } \\
\text { E-SQ } \rightarrow: 2\end{array}$ & 7.841 & 0.462 & Confirmed \\
E-LOY & & & \\
\hline
\end{tabular}

Table 8: Regression model of satisfaction on loyalty-line online

\begin{tabular}{|c|c|c|c|c|}
\hline $\begin{array}{c}\text { Independent } \\
\text { Variable }\end{array}$ & valuet & $\begin{array}{c}\text { Std. } \\
\text { Error }\end{array}$ & B & P \\
\hline Constant & & 0.223 & 2.926 & 0.004 \\
\hline $\begin{array}{c}\text { Online } \\
\text { Satisfaction }\end{array}$ & 0.462 & 0.063 & 7.841 & 0.000 \\
\hline
\end{tabular}

Table 9: regression analysis II: ANOVA

\begin{tabular}{|c|c|c|c|}
\hline Model & $\begin{array}{c}\text { Durbin- } \\
\text { Watson } \\
\text { Statistic }\end{array}$ & R2 & R2justified \\
\hline 1 & 1.85 & 0.812 & 0.792 \\
\hline
\end{tabular}

Table 10: Regression Analysis II: coefficients

\begin{tabular}{|c|c|c|c|c|c|c|}
\hline $\begin{array}{c}\text { M } \\
\mathbf{d} \\
\text { de } \\
\mathbf{l}\end{array}$ & & $\begin{array}{c}\text { sum } \\
\text { of } \\
\text { squa } \\
\text { res } \\
\text { (ols) }\end{array}$ & $\begin{array}{c}\text { d } \\
\mathbf{f}\end{array}$ & $\begin{array}{c}\text { Me } \\
\text { an } \\
\text { Squ } \\
\text { are }\end{array}$ & F & Sig. \\
\hline \multirow{2}{*}{1} & Regre & 71.89 & 2 & 35. & 63. & 0.00 \\
& ssion & 4 & & 947 & 933 & $0(a)$ \\
\cline { 2 - 7 } & Rema & 200.7 & 3 & 0.5 & & \\
& ining & 28 & 5 & 62 & & \\
& & & 7 & & & \\
\hline
\end{tabular}

As noted in Table 9. Durbin-Watson statistic of 1.85, which indicates the absence of autocorrelation in errors and therefore are entitled to the use of linear regression, statistics, R2, R2 adjusted 0.812 and 0.79R2espectively, which show that the regression model estimates about 79 percent of the electronic behavior of customer loyalty as the dependent variable explains. This main hypothesis of the present study confirms the second and fourth sub-hypothesis

Regression: Testing the relationship between the ECRM and mail-loyalty 
Assessment web site feature at any stage in the second and third leads to the formation of measure for each of the ECRM before you buy, ECRM ECRM when shopping was after purchase. Aim to achieve a regression analysis of the relationship between online loyalty as the dependent variable with ECRM before you buy, ECRM ECRM when buying and after buying as independent variables. The results are shown in Table 11 below. The adjusted R2 is 0.734, indicating significant relationship. Tables (11, 12 and 13) show Regression analysis results.

Table 11: Regression I: Summary Model

\begin{tabular}{|c|c|c|c|}
\hline Model & $\begin{array}{c}\text { Durbin-Watson } \\
\text { Statistic }\end{array}$ & R2 & R2Justified \\
\hline 2 & 1.93 & 0.751 & 0.734 \\
\hline
\end{tabular}

Table 12: Regression I: ANOVA

\begin{tabular}{|c|c|c|c|c|c|c|}
\hline Model & & $\begin{array}{c}\text { Sum of } \\
\text { Squares(ols) }\end{array}$ & df & $\begin{array}{c}\text { Mean } \\
\text { Square }\end{array}$ & F & Sig. \\
\hline 2 & Regression & 326.207 & 3 & 107.734 & 86.732 & $0.000(\mathrm{a})$ \\
\hline & Remaining & 423.783 & 356 & 1.253 & & \\
\hline
\end{tabular}

Table 13: Regression I: coefficients

\begin{tabular}{|c|c|c|c|c|c|}
\hline \multirow{3}{*}{ Constant } & \multicolumn{2}{|c|}{ Standard Coefficients } & \multirow[t]{2}{*}{$\mathbf{t}$} & \multirow{2}{*}{$\begin{array}{c}\boldsymbol{\beta} \\
\text { Standerized }\end{array}$} & \multirow[b]{2}{*}{ Sig. } \\
\hline & $\begin{array}{l}\text { Standard } \\
\text { Error }\end{array}$ & $\mathrm{B}$ & & & \\
\hline & 0.338 & -0.233 & -0.585 & & 0.514 \\
\hline $\begin{array}{c}\text { E-CRM } \\
\text { Before } \\
\text { Purchase }\end{array}$ & 0.089 & 0.967 & 54.234 & 0.227 & 0.000 \\
\hline $\begin{array}{c}\text { E-CRM } \\
\text { during } \\
\text { Purchase }\end{array}$ & 0.535 & 0.932 & 3.563 & 0.084 & 0.001 \\
\hline $\begin{array}{c}\text { E-CRM } \\
\text { after } \\
\text { Purchase }\end{array}$ & 0.064 & 0.956 & 4.679 & 0.267 & 0.000 \\
\hline
\end{tabular}

As noted in Table 11 of Durbin-Watson statistic is 1.93, which indicates the absence of autocorrelation in errors and therefore are entitled to the use of linear regression, statistics, R2, R2 adjusted 0.751 and 0.734 respectively, which show that the regression model estimates about 73 percent of the electronic behavior of customer loyalty as the dependent variable explains.

Regression: Testing the relationship between the ECRM and e-satisfaction

Assessment of site characteristics at each stage in the second and third causes the formation of scale for each of the ECRM before you buy, ECRM when buying and after buying out. Aim to achieve a regression analysis of the relationship between online satisfaction as the dependent variable with ECRM before you buy, ECRM ECRM when buying and after buying as independent variables. The results in Table 14 is given below. The adjusted R2 is 0.846, indicating significant relationship. Tables (14, 15 and 16) show Regression analysis results. 
Table 14: Regression I: Summary Model

\begin{tabular}{|c|c|c|c|}
\hline Model & $\begin{array}{c}\text { Durbin-Watson } \\
\text { Statistic }\end{array}$ & R2 & R2Justified \\
\hline 3 & 1.88 & 0.851 & 0.846 \\
\hline
\end{tabular}

Table 15: Regression I: ANOVA

\begin{tabular}{|c|c|c|c|c|c|c|}
\hline $\begin{array}{c}\text { Mod } \\
\text { el }\end{array}$ & & $\begin{array}{c}\text { Sum of } \\
\text { Squares(ol } \\
\text { s) }\end{array}$ & df & $\begin{array}{c}\text { Mean } \\
\text { Square }\end{array}$ & F & Sig. \\
\hline 4 & $\begin{array}{c}\text { Regress } \\
\text { ion }\end{array}$ & 373.941 & 2 & 107.654 & $\begin{array}{c}63.49 \\
1\end{array}$ & $0.000(\mathrm{a})$ \\
\cline { 2 - 7 } & $\begin{array}{c}\text { Remain } \\
\text { ing }\end{array}$ & 389.477 & 35 & 1.642 & & \\
\hline
\end{tabular}

Table 16: Regression I: coefficients

\begin{tabular}{|c|c|c|c|c|c|}
\hline \multirow[t]{2}{*}{ Constant } & \multicolumn{2}{|c|}{$\begin{array}{c}\text { Standard } \\
\text { Coefficients }\end{array}$} & \multirow[t]{2}{*}{$\mathbf{t}$} & \multirow{2}{*}{$\begin{array}{c}\beta \\
\text { Sta } \\
\text { nde } \\
\text { rize } \\
\text { d }\end{array}$} & \multirow[t]{2}{*}{ Sig. } \\
\hline & $\begin{array}{l}\text { Stand } \\
\text { ard } \\
\text { Error }\end{array}$ & B & & & \\
\hline & 0.563 & $\begin{array}{c}- \\
0.49 \\
9\end{array}$ & 5.642 & & 0.337 \\
\hline Web Features & $\begin{array}{c}0.060 \\
5\end{array}$ & $\begin{array}{c}0.74 \\
1\end{array}$ & 5.594 & $\begin{array}{l}0.3 \\
14\end{array}$ & 0.016 \\
\hline
\end{tabular}

As stated in the Durbin-Watson statistic of 2.31, which is 17 indicates the absence of autocorrelation in errors and therefore are entitled to the use of linear regression, statistics, R2, R2 adjusted 0.818 and 0.803 respectively, which show that the regression model estimates about 80 percent of the electronic behavior of customer loyalty as the dependent variable.

\section{Conclusion}

The final results of the evaluation of hypotheses presented in Table 20.

Table 20: To evaluate the hypothesis

\begin{tabular}{|c|c|c|c|}
\hline Hypothesis & Model & Comment & Result \\
\hline $\begin{array}{c}\text { first The main } \\
\text { hypothesis }\end{array}$ & Second & $\begin{array}{c}\text { There is loyalty among the website } \\
\text { features consumer electronics }\end{array}$ & Confirmed \\
\hline $\begin{array}{c}\text { Second The } \\
\text { main } \\
\text { hypothesis }\end{array}$ & first & $\begin{array}{c}\text { There is the satisfaction of users of e- } \\
\text {.loyalty customers }\end{array}$ & Confirmed \\
\hline $\begin{array}{c}\text { first Sub- } \\
\text { Hypothesis }\end{array}$ & Third & $\begin{array}{c}\text { There is a direct relationship between the } \\
\text { characteristics of E-CRM and e- } \\
\text { satisfaction before purchasing customers }\end{array}$ & Confirmed \\
\hline $\begin{array}{c}\text { Second Sub- } \\
\text { hypotheses }\end{array}$ & Third & $\begin{array}{c}\text { There is a direct relationship between the } \\
\text { characteristics of E-CRM and e- } \\
\text {.satisfaction when purchasing customers }\end{array}$ & Confirmed \\
\hline Third Sub- & Third & There is a direct relationship between the & Confirmed \\
\hline
\end{tabular}




\begin{tabular}{|c|c|c|c|}
\hline hypotheses & first & $\begin{array}{c}\text { characteristics of E-CRM and e- } \\
\text {.satisfaction after purchase customer } \\
\text {.satisfaction and e-loyalty }\end{array}$ & Confirmed \\
\hline $\begin{array}{c}\text { The fourth } \\
\text { hypothesis }\end{array}$ & Fifth Sub- \\
hypothesis & Second & $\begin{array}{c}\text { There is a direct relationship between the } \\
\text { characteristics of E-CRM and e-loyalty } \\
\text {.customers already buy }\end{array}$ & Confirmed \\
\hline $\begin{array}{c}\text { Sixth Sub- } \\
\text { hypothesis }\end{array}$ & Second & $\begin{array}{c}\text { There is a direct relationship between the } \\
\text { characteristics of E-CRM and loyalty } \\
\text {.when buying consumer electronics }\end{array}$ & Confirmed \\
\hline $\begin{array}{c}\text { Seventh Sub- } \\
\text { hypothesis }\end{array}$ & Second & $\begin{array}{c}\text { There is a direct relationship between the } \\
\text { characteristics of E-CRM and e-loyalty } \\
\text {.customers after purchase }\end{array}$ & Confirmed \\
\hline
\end{tabular}

Among the main elements of the website features before you buy, three features of web design, search capabilities and loyalty programs associated with user satisfaction and loyalty are positive and significant.

Among the main elements of the website features when buying, two privacy / security and payment methods associated with user satisfaction and loyalty are positive and significant.

Among the main elements of the website features after the purchase, three properties on-time delivery, and after-sale follow-purchase significant positive correlation with user satisfaction and loyalty of their users.

In summary, it can be concluded that the effect of the surface features of the website user satisfaction depends on user loyalty. A comprehensive process of recruiting and customer relationship entirely online will not be effective unless organizations active in the field of user satisfaction and loyalty they understand the importance and necessity of the web design and other features important and effective steps to adhere.

As is clear from the statements of the research, to gain online, online loyalty and establishment of electronic customer relationship management and knowledge and confirmed the following provisions:

Web Design

Search capabilities

Loyalty program implementation

Respect for personal privacy protection

Offers a variety of secure payment methods

Orders tracking

Timely delivery of orders

Quality Customer Service

It should be noted that the main limitation of this study is the large number of questions. On the one hand are the lack of detailed and proper investigation about customer e-satisfaction. 


\section{References}

Abesi, S., Shahtahmasebi, E. \& Imani, H. (2011). Identification And Prioritization of Favorable Factors and Conditions Related to Implementation of Customer Relationship Management (Case Study: Employers Insurance Company), A Fourth-Year Management Studies Spring, 2011, (11).

Anderson, K. \& Kerr, C. (2001). Customer Relationship Management, Mcgraw-Hill Education.

Anderson, R. E. \& Srinivasan, S. S. (2003). "E-Satisfaction and E-Loyyalty: A Contingency Framework”, Psychology and Marketing, Pp 123-138.

Asgharpoor, H., Fallahi, F., Khodadadkashi, F., Poorebadolhan, M. \& Dehghani, A. (2012). Relationship between the Impact of Innovation on Market Share in the Textile Industry, Leather and Clothing Iran. Journal of Economic Studies Economic Use of Bu-Ali Sina University, First Year, Issue 1. Pp.97-63.

Berry, L. L. (2002). Relationship Marketing of Services: Growing Internet, Emerging Perspectives, Journal of the Academy of Marketing Science, Vol.23, No. 4, Pp. 236-245.

Cao, Y., Gruca, T. S. \& Klemz, B. R. (2004). “Internet Pricing, Price Satisfaction, and Customer Satisfaction’”, International Journal of Electronic Commerce, Vol. 8, Pp. 31-50.

Chaffey, D., Mayer, R., Johnston, K. \& Ellis-Chadwick, F. (2003). Internet Marketing, Financial Times/Prentice Hall, Harlow.

Chandra, S. \& Strickland, T. J. (2004). Technological Differences Between CRM And Ecrm. Issues İn Information Systems, 5(2), 408-413.

Devaraj, S. Fan, M. \& Kohli, R. (2003). E-Loyyalty - Elusive İdeal or Competitive Edge? Communications of the ACM, 46(9), 184-191.

Feinberg, R., Kadam, R., Hokama, L. \& Kim, I. (2002). "The State of Electronic Customer Relationship Management in Retailing", International Journal of Retail \& Distributionmanagement, Vol. 30, No. 10.Pp. 470-481. Information Systems Frontiers, Vol. 5, Pp. 265-277.

Karimi, A. \& Mansooriyan, T. (2012). Review and Explain the Role of Customer Knowledge Management on Improving Organizational Performance, Quarterly Journal of Exploring Business, the Fourth Year, the Number 8, Pp. 92-75.

Khalifa, M. \& Shen, N. (2005). Effects of Electronic Customer Relationship Management on Customer Satisfaction: A Temporal Model, Proceedings of the 38th Hawaii International Conference on System Sciences-2005.

Khalifa, M. \& Shen, N. (2009). Modelling Electronic Customer Relationship Management Success: Functional and Temporal Considerations, Behaviour \& Information Technology, Vol. 28, No. 4, Pp, 373-387.

Lee, K. \& Joshi, K. (2006). Development of Integrated Model of Customer Satisfaction With Online Shopping. In Proceedings of the SIG MIS Conference. ACM Press, New York, NY, 53- 56.

Lin, C. S., Wu, S. \& Tsai, R. J. (2005). Integrating Perceived Playfulness İnto Expectation Confirmation Model for Web Portal Context. Information \& Management, Vol. 42, No. 5. Pp. 683-693. 
Liu, X., He, M., Gao, F. \& Xie, P. (2008). An Empirical Study of Online Shopping Customer Satisfaction in China: A Holistic Perspective. International Journal of Retail \& Distribution Management, Vol. 36 No. 11, Pp. 919-940.

Lu, J. (2003). A Model for Evaluating E-Commerce Based on Cost/Benefit And Customer Satisfaction.

Lynch, John \& Dan, Ariely (2000). "Wine Online: Search Costs and Competition on Price, Quality, and Distribution?' Marketing Science 19 (1): 83-103.

Oliver, R. L. (1997). Satisfaction: A Behavioural Perspective on the Consumer, 1st Edn, Mcgraw-Hill Co. Inc. New York.

Otim, S. \& Grover, V. (2006). “An Empirical Study on Web-Based Services and Customer Loyalty”, European Journal of Information Systems, Vol. 15 No. 6, Pp. 527-41.

Posselt, T. \& Gerstner, E. (2005). "Pre-Sale vs. Post-Sale E-Satisfaction: Impact on Repurchase İntention and Overall Satisfaction,” Journal of Interactive Marketing, Vol. 19, No. 4, Pp. 35-47.

Ross, D. F. (2005). E-CRM From a Supply Chain Management Perspective, Journal of Information Systems Management, Volume: 22, Issue: 1, Page 37-44.

Scullin, S., Allora, J., Lloyd, G. O. \& Fjermestad, J. (2002). "Electronic Customer Relationship Management: Benefits, Considerations, Pitfalls and Trends”, Proceedings of the IS One World Conference, Las Vegas, Nevada, April 3-5, CDROM.

Seeman, E. D. \& O’Hara, M. (2006). Customer Relationship Management in Higher Education. Using İnformation Systems to İmprove the Student-School Relationship. CampusWide Information Systems 23(1) 24-34.

Tarzi, N. \& Blooriyan, M. (2012). Evaluation of Critical Success Factors in Customer Relationship Management in Insurance Companies (Case Study: Saman Insurance), Journal of Business Management,16,97-81.

Wang, Y. S. \& Liao, Y. W. (2007). The Conceptualization and Measurement of M-Commerce User Satisfaction. Computers in Human Behaviour. Vol. 23, No (1) 381-398.

Zamanimoghadam, A. \& Lahiji, K. (2012). Factors Affecting Customer Loyalty in Private Banks Based on the Model of Rapid Responders, Marketing Management, the Fifth Year, The 16, PP.63-78. 